\title{
THE ANTARCTIC ECOSYSTEM
}

\author{
William S. Benninghoff \\ The University of Michigan Ann Arbor, Michigan 48109, USA
}

(Received 5 March 1986; Accepted 6 August 1986)

\begin{abstract}
The Antarctic region comprises the continent and surrounding sea south of the Antarctic Convergence, where cold Antarctic upper water sinks and mixes with warmer sub-Antarctic water. The continent, nearly centered on the South Geographic Pole, is isolated by the Southern Ocean from other land masses. The continent's mean elevation is about $2,000 \mathrm{~m}$ and $98 \%$ of the surface is mantled by $2,000 \mathrm{~m}$ or more of glacial ice which flows toward coastal outlets to the sea. The ice sheet is pierced by mountain summits, some approaching altitudes near $5,000 \mathrm{~m}$. The continental shelf mean width is $30 \mathrm{~km}$. On its seaward edge the shelf is at depths of 400 to over $600 \mathrm{~m}$. The total area of ice and snow surface presented by the region is doubled by the maximum extent of sea ice each year. The Antarctic Continent is the principal heat sink of the world weather machine. Upwelling areas of the Southern Ocean recycle nutrients and stimulate the marine ecosystem, and seasonal changes in extent of sea ice contribute to one of the greatest annual pulses in marine organic production. The fish fauna has only 120 species but these belong to 29 families. The zooplankton is rich in several endemic crustacea, notably the Antarctic krill. The only vertebrates on land come from the sea onto shore areas and fast ice, including colonies of breeding penguins and associated birds as well as seals. Closed communities of vascular plants and cryptogams occur on sub-Antarctic islands and the Antarctic Peninsula, but in the entire continental Antarctic the vegetation is desert-like, composed of scattered mosses, lichens, and terrestrial algae. Exposed surfaces of crystalline rocks harbor "endolithic microbial life," and a few species of invertebrates dwell on favorably exposed soil and under rocks. The ice Plateau is as nearly abiotic or sterile as any area on the earth's surface. The physical and biotic features of Antarctica represent extreme conditions. The continent was untouched by man until the past two centuries and remains nearly pristine. It yields key information about cold environments and global environmental systems including evidences of change, and deserves protection from unnecessary disturbance.
\end{abstract}

Most of the features of the Antarctic are anomalous in comparison with environments and biota of lower latitudes which are commonly regarded as "normal." Surrounded by seas that have been sailed for only 200 years, the only unpeopled continent has been explored just in the last 100 years. Yet the bounty of knowledge from scientific inquiry and logistic experience in Antarctica has already benefitted many disciplines and technologies in the rest of the world. The present prevailing view is that knowledge resulting from scientific inquiry on the continent and the surrounding ocean should be the objective of activity in that region for the foreseeable future. Through dedication and cooperation, the Antarctic Treaty nations, who provide the leadership in these undertakings, have already developed measures and precepts for conservation of species and environments in this region, but more needs to be done. Although the Antarctic is a vast region, lacking in indigenous peoples, and isolated from population centers, its environments and resident biotas could be easily dam- aged and are in need of specially designed protection and careful stewardship.

This paper sketches the background of the Antarctic as a regional ecosystem in order to provide a framework for the more sharply focused presentations to follow. Regarding the biotic community as the total of all populations living within a given area, this community and the totality of the nonliving environment functioning together are considered an ecological system or ecosystem (Evans, 1956). This concept can be applied to the entire earth (the biogeosphere) or to a cluster of lichens and their associated microbial life in a rock crevice. Obviously the lesser ecosystems are more or less connected and integrated with larger ones, so that boundaries in many instances are arbitrary and are commonly zones of interaction.

The Antarctic as a region may be defined as the continent and surrounding sea south of the Antarctic Circle, $66^{\circ} 33^{\prime} \mathrm{S}$, but this would fail to include the northern end of the Antarctic Peninsula and nearby islands. A more 
useful delimitation to identify the Antarctic ecosystem is the area within the Antarctic Convergence, the zone in the Southern Ocean where Antarctic upper water sinks below and mixes with warmer sub-Antarctic surface water (Phillpot, 1985; El-Sayed, 1985). The Convergence, generally between $50^{\circ}$ and $60^{\circ} \mathrm{S}$, is marked by a sharp change in sea and air temperatures and strong differences in the biota, especially the plankton and the sea birds. In contrast to "The Antarctic" as a region, "Antarctica" usually refers to the Antarctic Continent. The Antarctic Treaty provisions "shall apply to the area south of $60^{\circ}$ South Latitude, including all ice shelves, but nothing in the present Treaty shall prejudice or in any way affect the rights or the exercise of the rights, of any State under international law with regard to the high seas within that area" (Antarctic Treaty, Article VI, in U.S. Antarctic Program, 1977). The South Atlantic, Indian, and South Pacific Oceans surrounding the Antarctic Continent, when treated as the continentencircling ocean, are commonly subsumed under the term "Southern Ocean," an entity with clear integrity of distinctive currents and biota.

\section{Geography of the Antarctic}

The Antarctic Continent is nearly centered on the South Pole of the earth's axis, and is isolated by the Southern Ocean from other land masses, the nearest neighboring land being Tierra del Fuego, more than 800 $\mathrm{km}$ from the northern tip of the Antarctic Peninsula. The mean elevation of the continent is about $2,000 \mathrm{~m}$. Nearly all of the surface is mantled by $2,000 \mathrm{~m}$ or more of glacial ice which forms from snow and flows toward coastal outlets to the sea at rates of 10 to $1,000 \mathrm{~m} / \mathrm{yr}$ (Bentley et al., 1964; Radok, 1985). The major outlets are the ice shelves, especially the great ones, the Ross Ice Shelf and the Ronne Ice Shelf.

The ice sheet, which has an average thickness of 2,160 $\mathrm{m}$ (Radok, 1985) and attains more than 4,000 $\mathrm{m}$ above sea level near the center of the continent, is pierced by mountain summits, especially in the nearly continuous range of the Transantarctic Mountains which extend from Cape Adare (near $170^{\circ}$ East Longitude) across the continent to Coats Land (near $25^{\circ}$ West Longitude). A few of the summits are at altitudes of 4,500 to $5,000 \mathrm{~m}$. Other mountain summits emerge from the ice sheet near the margins of the continent. The load of the ice sheet has depressed the rock surfaces by about $600 \mathrm{~m}$ on the average, and it is believed that about one-third of the subglacial land surface now lies below sea level (Central Intelligence Aency, 1978). The ice sheet, in fact, binds the continent together; if the ice were removed, Lesser Antarctica (the Andean Province including the Antarctic Peninsula) would appear as an archipelago of mountainous islands alongside Greater Antarctica (the Gondwana Province), a land mass comparable to Australia.
The Andean axis is a part of the ring of tectonically and volcanically active mountains around the Pacific Ocean. Mount Erebus on Ross Island is an active volcano currently producing a steady plume of vapor.

The Continental Shelf is relatively narrow, the mean width of $30 \mathrm{~km}$ contrasting with a $70 \mathrm{~km}$ mean width for all continents. On its seaward edge the shelf is at depths of 400 to $600 \mathrm{~m}$, in places $800 \mathrm{~m}$, three to six times the depth of the mean for all continents (Central Intelligence Agency, 1978). This feature has been attributed to glacial action during past intervals of lower sea level or to depression by the weight of glacial ice.

The Southern Ocean is relatively deep, 4,000 to 5,000 m over most of its extent, with few and small areas of shallow water. Adjacent to the continent an east wind drift is the dominant current, but the greater part of the Southern Ocean is dominated by a west wind drift. At intermediate depths water flows southward until within several hundred kilometers of the continental shelf, where a portion rises to near-surface levels. This flows northward to the Convergence, while a larger portion sinks and forms the cold and high salinity Antarctic Bottom Water, which strongly influences benthic biota and processes of the Indian, Pacific, and, especially, Atlantic Oceans (El-Sayed, 1985). The cold bottom current flowing northward is one of the major components of the earth's heat balance system. As another factor in the earth's heat balance, the total area of the ice surface presented by the Antarctic region is doubled by the maximum area of sea ice each year, thus increasing the albedo of the region for more than one-half of the year (Gordon and Taylor, 1975).

\section{Atmosphere and Climate}

The troposphere, the layer of the atmosphere in which weather occurs, is only 9 to $12 \mathrm{~km}$ thick at the geographic poles, in comparison with 18 to $20 \mathrm{~km}$ at the Equator. Upper level tropospheric air, and probably some air from the lower stratosphere, descend onto the ice sheet and flow coastward and northward as part of the Hadley Cell circulation toward the Equator.

The cold climate is, to most minds, the salient feature of Antarctica. The Antarctic Continent is the principal heat sink of the world weather machine (Phillpot, 1985). The extreme minimum temperature recorded was $-89.6^{\circ} \mathrm{C}$ at Vostok in July 1983 . At places on the coast of the continent, especially where there is exposed rock, summer temperatures as high as $+9{ }^{\circ} \mathrm{C}$ and higher have been recorded (Phillpot, 1985). Precipitation on the continent is difficult to measure because it is in the form of snow, which is nearly always driven by wind, but most of the interior is believed to receive only 50 to 100 $\mathrm{mm}$ of water equivalent per year, making the continent one of the driest deserts. The climates of the northern portion of the Antarctic Peninsula and adjacent islands 
are, of course, more maritime, with less extreme low temperatures and more humid air, fog, and precipitation.

\section{Geology and Glaciology}

The Antarctic Continent has a wide variety of rock types, with some major differences in rocks and structures between Greater and Lesser Antarctica. Greater Antarctica is composed of older terrane units and granitic rocks, metamorphics, metasediments, sediments, and various older intrusives. In the younger, Andean, Lesser Antarctica there are greater proportions of sediments and metasediments, along with younger intrusives and volcanics (Elliot, 1985). Physical weathering of rocks is dominant; erosion by glacial abrasion, erosion by windblown snow, fracturing and spalling of rocks by strong temperature changes with or without water are common processes. The presence of even minute quantities of free water may cause solution and then evaporative precipitation of salts that can force apart mineral crystals in rocks. Soils with discernible profiles are unknown except on the sub-Antarctic islands. In the desert-like dry atmosphere of the continent, strong winds driving snow crystals and in some places sand or silt as well, accomplish considerable erosion and sculpturing of exposed rock surfaces. Wind and snow abrasion also restrict plant growth on exposed sites.

The vast Antarctic ice sheet is proving to be a remarkable sedimentary record of atmospheric gases $\left(\mathrm{CO}_{2}\right.$, $\mathrm{CH}_{4}$ ) and minute airborne particles (especially volcanic ash). Cores to depths over 1,000 $\mathrm{m}$ have extended these records back into the last interglacial or more than 100,000 years (Radok, 1985).

Polar ice sheets and glaciers, such as those of the Antarctic Continent Plateau, are distinctive because they undergo ablation not by melting, but rather primarily by sublimation (water changing phase from ice to vapor without going through the liquid phase). Thus meltwater streams and sediments are lacking. Without silt bars in meltwater streams there is no windblown loess. In fact, there is a general scarcity of silt- and clay-size sediments in Antarctica. Under the desert-like climate and limited precipitation, it is not surprising that there is a general scarcity of surface water and a lack of subsurface water. With negative heat balance prevailing over nearly all of the Continent, the ground has permafrost, that is, the ground is perennially below freezing to great depths. If any water is present below the thin active (freeze-thaw) layer at the surface, it is frozen. In some of the Dry Valleys of Victoria Land there are a few small stream beds that infrequently carry water. Along those water courses and on a few slopes receiving small amounts of melt water, the soils have their rocks sorted by frost action into patterned ground, especially as polygons. However, there is so little free water on the surface or in the soils that dramatic ice-segregation features (palsas, pingoes) like those in the Arctic cannot develop. In contrast to the cold desert features of the Continent, the maritime Antarctic and the Sub-Antarctic Islands have temperatures near the freezing point, moderate precipitation, and wide varieties of frost effects in the soils.

\section{The Antarctic Marine Biome}

The Southern Ocean came into being as South America and Africa drew away from the Antarctic Continent and spread apart, Peninsular India and later Australia drifted northward, and the Antarctic Continent moved into its present position with the geographic South Pole near its center (Elliot, 1985). As a consequence, the Antarctic Continent became isolated and surrounded by a continuous sea with relatively fast circumpolar currents. About 38 million years ago (at approximately the EoceneOligocene boundary) the Cold Bottom Water from the continental margin began to flow northward. This regime, which dropped the bottom water temperatures from about $10^{\circ} \mathrm{C}$ to $5^{\circ} \mathrm{C}$, took place over a relatively short interval, probably no longer than 100,000 years (Hammond, 1976). There is evidence that many bottom and abyssal species were killed, and widespread seafloor erosion left gaps in the sedimentary record. The most recent fossil terrestrial floras of temperate plants are found in the Eocene or Oligocene of Seymour Island near the tip of the Antarctic Peninsula. The Antarctic climate evidently cooled rapidly after that time.

The Southern Ocean is a circumglobal sea with strong currents. There is a general northward drift from the continental margin by both the surface water and the Antarctic bottom water. At intermediate depths warmer circumpolar deep water flows southward toward the continent, and it carries nutrients from intermediate depths farther north. Some of the circumpolar deep water is carried toward the surface, especially in the eddies of the Antarctic Divergence between the continenthugging east wind drift and the more peripheral west wind drift. These eddies are upwelling areas in which phytoplankton flourish on the additional nutrients, thus stimulating the entire marine ecosystem in the local area (El-Sayed, 1985).

Sea ice surrounds the Continent throughout the year. The seasonal changes in its extent contribute to one of the greatest pulses of organic production on earth. The sea ice expands from an area of about 4 million $\mathrm{km}^{2}$ at the end of summer to 22 million $\mathrm{km}^{2}$ by late winter (Gordon and Taylor, 1975). This is a pulsating ecotone, an annually renewing habitat to be recolonized each year by sessile plankton and associated nekton. The sea ice, broken and battered by tides, winds, and waves, becomes jumbled and re-formed with variety in salt concentrations and light transmission quality at different sites, so that by late winter the ice cover becomes a sur- 
face of diverse habitats for the under- and within-ice biota. Enhanced growth of the plankton beneath the ice begins shortly after the sunlight starts to return with lengthening days. As the northern margin of the ice retreats southward during the summer, a zone of vigorously growing algae and associated plankton follows in its wake (Laws, 1985; El-Sayed, 1985). This annual process is part of the basis for the high productivity of the Southern Ocean, but the process is still not well known and understood.

Intensified study of the Southern Ocean and its productivity by the BIOMASS Program, the largest International biolgoical investigation ever conducted in complete concert, has demonstrated the stochastic nature of the dominant species populations, such as the Antarctic krill (Euphausia superba), and it has revealed other large gaps in knowledge of this system (Everson, 1984b). One problem area is what goes on under the sea ice, and in particular, how do algae we know to be autotrophic survive 4 or 5 months of darkness. Another key problem is how decomposition processes keep pace with production. Bacterial populations do not appear to be adequate. Have we overlooked marine Phycomycetes or other decomposer organisms?

The fauna of the Southern Ocean is not especially rich in species diversity, but it is distinctive. The fish fauna comprises only 120 species, but these belong to 29 families, with the dominant group being the Nototheniiformes, including the white-blooded fishes endemic to this ocean (Everson, 1984a). These fishes are adapted to oxygen-rich and cold water. The zooplankton is composed largely of several endemic crustacea, notably the Antarctic krill, the dominant herbivore south of the west wind drift and a major contributor to the large secondary and tertiary production levels of the Southern Ocean. The Southern Ocean ecosystem has undergone two strong perturbations in the recent past, the near extirpation of the fur seals during the last century (Bonner, 1985) and the extreme reduction of the baleen whale populations in the present century (Gambell, 1985). It is believed that one consequence of those reductions in the populations of several marine mammals has been to allow increases in populations of other krill-eating species of seals and penguins.

On most of the Antarctic coasts where there are accessible shorelines, great colonies of breeding penguins, numbering in the tens of thousands, spend a good part of 8 to 10 weeks at the nesting-hatching process (Stonehouse, 1985). Scavenger birds and birds of prey attach themselves to the colonies. The guano from the krilleating penguins enriches the local soils with nutrients from the sea, an import of considerable significance to the relatively poor soils.

\section{Antarctic Terrestrial Biome}

Various attempts have been made to subdivide the south polar terrestrial regions on the basis of vegetation.
The concepts have been recently sorted out and reorganized into three geobotanical regions: the Sub-Antarctic, the Maritime Antarctic, and the Continental Antarctic, each with several provinces (Lewis-Smith, 1984). The Sub-Antarctic region comprises South Georgia (South Atlantic province), Macquarie Island (South Pacific province), and Marion and Prince Edward Islands, Heard and McDonald Islands, Iles Crozet, and the Iles Kerguelen (South Indian Ocean province). These islands have cool climates, and annual mean temperatures above $0{ }^{\circ} \mathrm{C}$. Their temperature fluctuations throughout the year are relatively small, permafrost is absent from most of the islands, and soil freezing occurs only on the coldest days (except on South Georgia and Heard Island). The vegetation consists of extensive closed communities of vascular plants in the lower altitudes and scattered cryptogamic communities at higher altitudes. It is curious that Sphagnum mosses are absent in the Antarctic regions, even in these islands (apart from South Georgia). Sea birds and marine mammals are abundant near the shores, and there are also some land birds, many insects, spiders, earthworms, and molluscs.

The Maritime Antarctic comprises the South Sandwich, South Orkney, and South Shetland Islands, and the Antarctic Peninsula's west side and its adjacent islands south to approximately $70^{\circ}$ South Latitude. The northern part has a cold moist maritime climate, winter temperatures rarely below $-10^{\circ} \mathrm{C}$, and precipitation $350-500 \mathrm{~mm} / \mathrm{yr}$ with much falling as rain in summer. On surfaces not covered by ice, cryogenic formations are abundant: frost-cracking, stone nets, and other structure soils, and solifluction features. Periglacial environments provide high diversity of habitats and many recombinations of plant associations. The vegetation is primarily of mosses, which form closed communities in wetter habitats and accumulate peat, and lichens, which mantle rocks and exposed sites, especially inland. In the Southern province the diversity of cryptograms is less, closed communities are more restricted, mosses do not form peat, and Diptera (flies) are rare. In many places throughout this region the two phanerogams of the Antarctic occur (a grass, Deschampsia antarctica, and a member of the Pink family, Colobanthus quitensis), forming restricted swards in the Northern province and much more scattered and infrequent tufts in the Southern province (Longton, 1985). Throughout this region the sea bird and marine mammal faunas are abundant on the shores in summer.

The main and far more extensive region, roughly south of $66^{\circ} 33^{\prime}$ South Latitude, is generally called the Continental Antarctic and is subdivided into Coastal, Slope, and Ice Plateau provinces (Holdgate, 1970; Lewis-Smith, 1984). The entire area is cold and arid, with permanent ice that covers about $98 \%$ of the surface and is interrupted only by protruding mountain summits (nunataks, a term borrowed from Greenland) and coastal headlands and dry valleys. The Coastal province has localities 
where the mean temperature of one summer month is as high as $1^{\circ} \mathrm{C}$ and annual precipitation is more than $100-150 \mathrm{~mm}$ of water equivalent with rain occurring on rare occasions. The vegetation is desert-like to semidesert, composed of sparse populations of a few species of mosses, lichens, and terrestrial algae (Greene et al., 1967). Snow algae occur locally. Ground-dwelling invertebrates are locally abundant and diverse. Seabirds, primarily penguins, in large colonies occupy many of the shelving shores in summer. The Slope province is the zone of mountains and outlet glaciers between the coast and the central ice plateau. This zone is colder and drier than the Coastal province; all mean monthly temperatures are below $-5{ }^{\circ} \mathrm{C}$, the annual precipitation probably does not exceed $100 \mathrm{~mm}$ water equivalent, and there is no rain. The vegetation is desert-like, in that there are no continuous patches or swards; the few species of mosses, lichens, and terrestrial algae are in scattered, minute tufts. Exposed surfaces of rocks with crystalline structure like sandstone harbor "endolithic microbial life" including algae and fungi within the weathering surface layers (Friedmann, 1982). A few species of invertebrates, particularly mites and springtails, dwell on exposed ground and under rocks. The Ice Plateau province has the most extreme continental climate. All mean monthly temperatures are below $-15^{\circ} \mathrm{C}$ and well below $-30^{\circ} \mathrm{C}$ in winter. Precipitation is less than $100 \mathrm{~mm} / \mathrm{yr}$ of water equivalent, all as snow and difficult to measure because of almost continuous strong winds. The only traces of life on the Plateau are occasional microorganisms and stray birds. This province is as nearly abiotic or sterile as any area on the earth's surface and deserves protection against the chance its very sterility may be a useful resource in the future, as perhaps an isolation area for samples brought from other bodies in the solar system.

The Ice Plateau province has its northern boundary nearly coinciding with the isoline for zero radiation balance. On the ice-free areas the radiation balance may reach $+20-40 \mathrm{kcal} / \mathrm{m}^{2} \cdot \mathrm{yr}$ in contrast with the balance over glacial ice cover which is always negative. Throughout this province the relative humidity is low, commonly less than $50 \%$ and in föhn winds even less than $10 \%$. Consequently, evaporation may be $500 \mathrm{~mm} / \mathrm{yr}$ where the precipitation is only $200-300 \mathrm{~mm}$. Under this climate snow and ice sublime rather than melt, so there are few glaciofluvial features, and the intensive evaporation over thousands of years has left surface waters and soils rich in salts. The resident organisms contend constantly with cold and dessication. Such small ecosystems as exist in rock crannies and protected soil sites comprise representatives of some or all of the groups of mosses, lichens, algae, and several genera of minute arthropods, undoubtedly accompanied by fungi and bacteria functioning as decomposers. The communities are simple recombinations of these few elements and the food chains are short. These miniature systems are among the simplest known and are matched only by communities in several other extreme environments such as mountain summits in the nival zone and hot deserts.

\section{Antarctic and Arctic Regions Compared}

The two polar regions of the earth have some basic characteristics in common-low temperatures, long winter darkness, long summer daylight, most of the precipitation as snow, extensive accumulations of glacial ice - but beyond these shared features of seasonal insolation and general climate, the two regions have little in common. In fact, they are more in contrast than similar. The Antarctic has a continental land mass as its central and dominant feature surrounded by a circumglobal ocean broadly connected with the other great oceans. The Arctic consists of a "mediterranean" basin occupied by the Arctic Ocean, which is nearly landlocked except for outlets in the Norwegian Sea and Denmark Strait and the minor connection with the Pacific through the Bering Strait. The large island of Greenland supports an ice sheet that is about one-tenth the extent of the Antarctic ice sheet, and the sea ice of the Arctic Ocean is considerably less extensive than that of the Antarctic, with correspondingly greater solar heating of the Arctic. Great contrasts are shown in the flora and fauna of the two regions. The Arctic, up to the shores of the Arctic Ocean, is populated by plants and animals that have affinities with alpine and montane biotas extending into temperate regions, whereas the Antarctic Continent has a limited terrestrial biota that is isolated by large distances across oceans from other land masses. The Arctic Ocean fauna is not rich and has few endemics; it consists mostly of species derived from the North Atlantic. The faunas of the Southern Ocean surrounding the Antarctic Continent, however, are rich in endemic species, many of which exhibit special adaptations to their cold environment. Dunbar (1968) pointed out that the Antarctic biota gives evidence of some antiquity, at least several millions of years of evolutionary development, in contrast to "characteristics of the Arctic ecosystem which can perhaps best be interpreted as those of youth and immaturity, of imperfect adaptation to recent environmental change ..." (Dunbar, 1968, p. 4). A part of the value of the Arctic and Antarctic regions to science lies in the contrasts between the two.

\section{Conclusions}

The physical and biotic features of Antarctica, for the most part, represent extreme conditions-isolation, cold, windiness, extensive glacial ice and sea ice, depauperate terrestrial biota, and abundant marine biota. Antarctica was untouched by man until the past two centuries and is still almost pristine. It yields key information about global systems such as heat budget, magnetism, atmospheric electricity, plate tectonics, ocean 
currents, and ocean chemistry. Many of the Antarctic components in these global systems are in sensitive balance and thus are useful for monitoring environmental changes. The biotic systems comprise organisms and food chains that are extraordinarily adjusted to harsh conditions. The organisms are valuable sources of knowledge about physiological, ecological, and evolutionary response to stressful environments, especially cold, polar darkness, sea ice, and terrestrial snow, ice, and dessication.

These are all reasons for protecting the Antarctic environments and resources against unnecessary disturbance. Some scientific investigations may cause a degree of degradation to environments and resident organisms, but these studies are the sources of information essential for optimum management of the areas and biotas of concern. The Antarctic offers fascinating attractions for tourists, who, if properly led and instructed, will cause little distrubance and will take home special appreciation for the region. The challenge to us is to apply our best scientific probing and thinking to advancement of knowledge of the Antarctic environment, its living systems and nonliving resources, while using the available information to improve our stewardship of the region.

\section{References}

Bonner, W. M. (1985) Birds and mammals - Antarctic seals, in Key Environments Antarctica, W. M. Bonner and D. W. H. Walton, eds., pp. 202-222. Pergamon Press, Oxford.

Bonner, W. N. and Walton, D. W. H., eds. (1985) Key Environments Antarctica. Pergamon Press, Oxford.

Bentley, C. R., Cameron, R. L., Bull, C., Kojima, K., and Gow, A. J. (1964) Physical characteristics of the Antarctic Ice Sheet. Antarctic Map Folio Series, folio 2, American Geographical Society, New York, NY.

Central Intelligence Agency (1978) Polar Regions Atlas. CIA, Washington, $D C$.
Dunbar, M. J. (1968) Ecological Development in Polar Regions. Prentice-Hall, Englewood Cliffs, NJ.

Elliott, D. H. (1985) Physical geography - geological evolution, in Key Environments Antarctica, W. M. Bonner and D. W. H. Walton, eds., pp. 39-61. Pergamon Press, Oxford.

El-Sayed, S. Z. (1985) Plankton of the Antarctic Seas, in Key Environments Antarctica, W. M. Bonner and D. W. H. Walton, eds., pp. 135-153. Pergamon Press, Oxford.

Evans, F. C. 1956. Ecosystem as the basic unit in ecology, Science $123,1127-1128$

Everson, I. (1984a) Fish biology, in Antarctic Ecology, R. M. Laws, ed., vol. 2, pp. 491-532. Academic Press, London.

Everson, I. (1984b) Marine interactions, in Antarctic Ecology, R. M. Laws, ed., vol. 2, pp. 783-819. Academic Press, London.

Friedmann, E. I. (1982) Endolithic micro-organisms in the Antarctic cold desert, Science 215, 1045-1053.

Gambell, R. (1985) Birds and mammals-Antarctic whales, in Key Environments Antarctica, W. M. Bonner and D. W. H. Walton eds., pp. 223-241. Pergamon Press, Oxford.

Gordon, A. L. and Taylor, H. W. (1975) Seasonal change of Antarctic sea ice cover, Science 187, 346-347.

Greene, S. W., Gressitt, J. L., Koob, D., Llano, G. A., Rudolph, E. D., Singer, R., Steere, W. C., and Ugolini, F. C., eds. (1967) Terrestrial life of Antarctica. Antarctic Map Folio Series, folio 5. American Geographical Society, NY.

Hammond, A. L. (1976) Paleoceanography: Sea floor clues to earlier environments, Science 191, 168-170.

Holdgate, M. W., ed. (1970) Antarctic Ecology, vol. 2. pp. 729-732. Academic Press, London.

Laws, R. M., ed. (1984) Antarctic Ecology. 2 vols. Academic Press, London.

Laws, R. M. (1985) The ecology of the Southern Ocean, Am. Scientist $72,26-40$.

Lewis-Smith, R. I. (1984) Terrestrial plant biology, in Antarctic Ecology, R. M. Laws, ed., vol. 1, pp. 61-162. Academic Press, London.

Longton, R. E. (1985) Terrestrial habitats-vegetation, in Key Environments Antarctica, W. M. Bonner and D. W. H. Walton, eds., pp. 73-105. Pergamon Press, Oxford.

Phillpot, H. R. (1985) Physical geography-climate, in Key Environments Antarctica, W. M. Bonner and D. W. H. Walton, pp. 23-28. Pergamon Press, Oxford.

Radok, Uwe, (1985) The Antarctic ice, Scientific Am. 215, 98-105.

Stonehouse, B. (1985) Birds and mammals - Penguins, in Key Environments Antarctica, W. M. Bonner and D. W. H. Walton, eds., pp. 266-292. Pergamon Press, Oxford.

U. S. Antarctic Program (1977) Personnel manual. National Science Foundation, Washington, DC. Antarctic Treaty, pp. 53-58. 